\title{
DANA PIHAK KETIGA DAN FAKTOR-FAKTOR YANG MEMPENGARUHINYA PADA PERBANKAN SYARIAH DI INDONESIA
}

\author{
Dewi Sartika \\ Ikatan Ahli Ekonomi Islam \\ dewi.sartika@gmail.com
}

\begin{abstract}
.
This study examines the effect of GDP (Gross Domestic Product) and the exchange rate on U.S. dollar against the TPF (Third Party Funds) in Indonesia. The objective of Islamic banking in this study was to analyze the influence of GDP (Gross Domestic Product) Rupiah rate against U.S. dollar deposits (Fund Party Third) of Islamic banking in Indonesia. In writing this makes the GDP (Gross Domestic Product) and the rupiah rate to U.S. dollar as the variables that influence to measure how much influence on Deposits (Third Party Funds). This study used 24 samples comprising the financial statements starting from January 2004 till December 2009. The method used in this study is the statistical method with a multiple regression model, where to find or measure how much influence given by the GDP (Gross Domestic Product) and exchange rate on U.S. dollar against the TPF (Third Party Funds) Islamic banking. The result showed that the variables GDP (Gross Domestic Product) and the exchange rate on U.S. dollar deposits have a significant effect on the Fund (Third Party) Islamic banking in Indonesia.
\end{abstract}

Keywords: GDP; Exchange Rate; Third Party Funds.

\begin{abstract}
Abstrak.
Penelitian ini menguji pengaruh PDB (Produk Domestik Bruto) dan nilai tukar, Dana Pihak Ketiga di Indonesia. Tujuan dari penelitian ini adalah untuk menganalisis pengaruh PDB (Produk Domestik Bruto) tingkat nilai tukar, Dana Pihak Ketiga perbankan syariah di Indonesia. Penelitian ini menggunakan 24 sampel yang terdiri dari laporan keuangan yang dimulai dari Januari 2004 sampai Desember 2009. Metode yang digunakan dalam penelitian ini adalah metode statistik dengan model regresi berganda, di mana untuk menemukan atau mengukur seberapa besar pengaruh yang diberikan oleh GDP (Produk Domestik Bruto) dan nilai tukar dolar AS terhadap TPF (Dana Pihak Ketiga) perbankan syariah. Hasil penelitian menunjukkan bahwa variabel PDB (Produk Domestik Bruto) dan nilai tukar memiliki pengaruh yang signifikan pada Dana (Pihak Ketiga) perbankan syariah di Indonesia.
\end{abstract}

Kata Kunci: PDB; Nilai Tukar; Dana Pihak Ketiga.

Diterima: 30 Juli 2013; Direvisi: 22 September 2013; Disetujui: 1 Oktober 2013 


\section{PENDAHULUAN}

Pada saat krisis melanda Negara kita, perbankan menjadi intitusi yang tidak luput dari cemoohan public. Institusi ini dianggap sebagai institusi yang turut serta dan bertanggung jawab dalam ketepurukan perekonomian Negara. Mengapa demikian? $\mathrm{Hal}$ yang sangat mendasar adalah karena fungsi yang sangat strategis yang diemban oleh perbankan yaitu dalam kaitannya menjadi stimulus perekonomian suatu Negara.

Dilihat dari indikator nilai Produk Domestik Bruto (PDB), perekonomian Indonesia terus menunjukkan perbaikan. Sepanjang periode 2004 sampai 2009 secara rata-rata PDB Indonesia mengalami fluktuasi yang cenderung meningkat. Terjadinya depresiasi perekonomian tidak terlepas dari krisis mata uang rupiah terhadap dollar USA yang terdepresiasi hingga ratusan persen pada pertengahan tahun 1997 hingga akhir tahun 1998. Nilai tukar rupiah terhadap dollar USA mengalami stabilisasi setelah tahun 2000 walaupun masih sedikit mengalami fluktuasi. Serta krisis ekonomi tahun 1997 membuat perbankan nasional waktu itu terpuruk krisis yang dipicu oleh memburuknya nilai tukar rupiah terhadap dolar USA, sehingga memicu terjadinya peningkatan kredit bermasalah. Hal inilah yang kemudian regulator membandingkan Bantuan Likuiditas Bank Indonesia (BLBI) yang hingga sekarang masih menuai kontrovesi.

Sementara pada krisis kedua tahun 2008 yang dikenal dengan krisis global negeri ini hanya terimbas dampak krisis. Nilai tukar rupiah hampir menyentuh Rp. 13.000 atau terdepresiasi hingga 26,2 persen. Akibat memburuknya daya beli di beberapa Negara tujuan ekspor, industripun mulai lesu dengan menurunnya permintaan. Diperkirakan krisis ini belum akan berhenti memakan korban, mengingat peristiwa gegar ekonomi kali ini dikuti dengan kecenderungan penurunan harga-harga komoditas, di bursa komoditi Internasional. Petani sawit, misalnya mulai gelisah, CPO, yang semula menjadi primadona ekspor, mengalami penurunan drastis, hingga panen sawit petani dibiarkan membusuk karena harga sawit menurun drastis dari RP. 2.400 per $\mathrm{kg}$ menjadi antara Rp. 250-350 per kg nya.

Adanya bank syariah yang beroperasi dengan tujuan utama menggerakan perekonomian secara produktif. Disamping sungguh-sungguh menjalankan fungsi intermediasi karena secara syariah tugas bank selaku mudharib (pengelola dana) harus menginvestasikan pada sektor ekonomi secara riil untuk kemudian berbagi hasil dengan shahibul maal (pemilik dana) sesuai dengan nisbah yang disepakati. Hal ini terbukti, meskipun market share bank syariah masih sangat kecil yaitu kurang dari $1 \%$, 
namun rasio pembiayaan dengan dana pihak ketiga lebih dari $100 \%$ yang berarti bank telah menjalankan fungsi intermediasinya tersebut. Masih kecilnya market share itu disebabkan antara lain karena bank syariah mempunyai keterbatasan dana baik dari segi permodalan maupun jumlah dana masyarakat yang berhasil di himpun.

Sebagai lembaga keuangan dengan fungsi intermediasi bergantung pada sumber permodalan untuk menjalankan fungsinya. Dana adalah uang tunai yang dimilki atau dikuasai oleh bank dalam bentuk tunai, atau aktiva lain yang dapat segera diubah menjadi uang tunai. Uang tunai yang dimiliki atau dikuasai oleh bank tidak hanya berasal dari pemilik bank itu sendiri, tetapi juga berasal dari titipan atau penyertaan dana oaring lain atau pihak lain yang sewaktuwaktu atau pada saat tertentu akan ditarik kembali, baik sekaligus ataupun secara berangsur-angsur.

Perbankan syariah meningkat sebesar 30,1 \% (yoy) atau 23,8 \% (ytd) yang didukung oleh pertumbuhan pembiayaan sebesar 19,5 (ytd), sedangkan dari sisi pendanaan, DPK yang bertumbuh 25,1\% (ytd) menggambarkan bahwa produk-produk simpanan perbankan syariah semakin diminati oleh masyarakat. Sementara itu, dari aspek fungsi intermediasi perbankan syariah tetap menjalankan fungsi intermediasinya dengan baik, dimana Financing to Deposit Ratio (FDR) mencapai nilai 95,49\% lebih besar dibandingkan Loan to Deposit Ratio (LDR) perbankan nasional. Namun demikian, pada triwulan IV-2009 (data per akhir November 2009) terdapat kecenderungan peningkatan resiko pembiayaan, dimana rasio Non Performing Financing (NPF) bank umum syariah dan unit usaha syariah mencapai $5,54 \%$.

Oleh karena itu dengan melihat betapa pentingnya faktor Dana Pihak Ketiga bagi perbankan syariah untuk menjalani fungsinya sebagai penghubung antara pemilik modal dengan pengusaha, maka untuk itu mencoba untuk mengindikasikan faktorfaktor yang mempengaruhi dana pihak ketiga perbankan syariah di Indonesia, faktorfaktor tersebut adalah PDB (Produk Domestik Bruto) dan Kurs rupiah terhadap Dollar Amerika.

Dalam ekonomi mikro, pendapatan (Y) seorang individu dapat digunakan untuk konsumsi (C) dan menabung (S), yang secara matematis dirumuskan sbb : 
$Y=C+S$

Keterangan :

$$
\begin{aligned}
& \mathrm{Y}=\text { Pendapatan } \\
& \mathrm{C}=\text { Konsumsi } \\
& \mathrm{S}=\text { Tabungan }
\end{aligned}
$$

Bila ada banyak orang maka dalam ekonomi makro pendapatan semua orang yang berada dalam satu Negara disebut Pendapatan Domestik Bruto (PDB) atau GDP (Gross Domestic Product) yang secara matematis dituliskan sbb :

$\sum \mathrm{Y}=\Sigma \mathrm{C}+\Sigma \mathrm{S}$

Keterangan :

$$
\begin{aligned}
& \Sigma Y=\text { Agregat Pendapatan } \\
& \Sigma C=\text { Agregat Konsumsi } \\
& \Sigma S=\text { Agregat Tabungan } \\
& \text { PDB (Produk Domestik Bruto) }
\end{aligned}
$$

Pendapatan nasional adalah merupakan suatu kerangka perhitungan (accounting framework) yang digunakan untuk mengukur aktivitas ekonomi yang terjadi atau berlangsung di dalam perekonomian.

Kurs rupiah terhadap dollar AS Kurs valuta asing atau kurs mata uang asing menunjukan harga atau nilai mata uang Negara dinyatakan dalam nilai mata uang Negara lain.

\section{Bank Syariah}

Bank Syariah adalah bank yang beroperasi dengan tidak mengandalkan pada bunga. Bank Islam atau biasa disebut dengan Bank tanpa Bunga, adalah lembaga keuangan/perbankan yang operasional produknya dikembangkan berlandaskan pada al-Qur'an dan Hadits Nabi SAW. Bank Syariah adalah lembaga keuangan yang usaha pokoknya adalah menyediakan dana untuk pembiayaan usaha secara nyata, disebut sebagai sektor riil, dan jasajasa lain seperti halnya gerak operasional perbankan umum, dalam lalu lintas pembayaran serta peredaran uang yang beroperasi sesuai dengan prinsip-prinsip Syariah (Muhammad, 2005). 


\section{Pengertian Sumber Dana Bank}

Pengertian sumber dana bank adalah usaha bank dalam menghimpun dana dari masyarakat. Perolehan dana ini tergantung dari bank itu sendiri, apakah dari simpanan masyarakat dari lembaga lainnya (Kasmir, 2003).

\section{Dana Pihak Ketiga}

Modal yang dimiliki bank sebagian besar berasal dari Dana Pihak Ketiga (DPK) sesuai dengan salah satu fungsi bank yaitu menghimpun dana dan menyalurkannya kepada masyarakat (Siamat, 2004).

\section{Produk Domestik Bruto}

\section{Pengertian PDB}

Menurut Paul A. Samuelson, "Produk Domestik Bruto (PDB) atau Gross Domestic Product (GDP) merupakan nama yang kita berikat untuk total nilai pasar dari barang jadi dan jasa yang dihasilkan dalam suatu Negara selama satu tahun tertentu (Samuelson dan Nordhanus, 2004).

\section{Perhitungan Pendapatan Nasional}

Peritungan pendapatan nasional (national income accounting) menunjuk kepada seperangkat aturan (rules) dan teknik (techniques) untuk mengukur aliran seluruh output barang dan jasa yang dihasilkan dan aliran seluruh input (faktor-faktor produksi) yang digunakan oleh suatu perekonomian untuk menghasilkan output barang dan jasa tersebut. Dengan perkataan lain, perhitungan pendapatan nasional adalah merupakan suatu kerangka perhitungan (accounting framework) yang digunakan untuk mengukur aktivitas ekonomi yang terjadi atau berlangsung di dalam perekonomian (Muana Nanga, 2001).

\section{Kurs}

Kurs adalah sebuah mata uang dari suatu Negara yang diukur/dinyatakan dalam satuan mata uang lainnya. Kurs memainkan peranan yang amat penting dalam keputusan-keputusan pembelanjaan, karena kurs memungkinkan bagi kita untuk menerjemahkan harga-harga dari berbagai Negara ke dalam satu bahasa yang sama. Ada beberapa faktor yang mempengaruhi pergerakan nilai tukar, yaitu :
a. Faktor fundamental
b. Faktor teknis
c. Sentimen pasar 


\section{Hipotesis}

1. $\mathrm{H}_{0}: \mathrm{b}=0$; Variabel PDB (Produk Domestik Bruto) dan Kurs Rupiah terhadap Dollar AS tidak berpengaruh secara parsial terhadap DPK (Dana Pihak Ketiga) $\mathrm{H}_{1}: \mathrm{b} \neq 0$; Variabel PDB (Produk Domestik Bruto) dan Kurs Rupiah terhadap Dollar AS berpengaruh secara parsial terhadap DPK (Dana Pihak Ketiga)

2. $\mathrm{H}_{0}: \mathrm{b}=0$; Variabel PDB (Produk Domestik Bruto) dan Kurs Rupiah terhadap Dollar AS tidak berpengaruh secara simultan terhadap DPK (Dana Pihak Ketiga) $\mathrm{H}_{1}: \mathrm{b} \neq 0$; Variabel PDB (Produk Domestik Bruto) dan Kurs Rupiah terhadap Dollar AS berpengaruh secara simultan terhadap DPK (Dana Pihak Ketiga)

\section{METODE}

Metode analisis yang digunakan untuk menguji hipotesis adalah metode Regresi Linier Berganda, yaitu regresi yang digunakan untuk mengetahui seberapa besar pengaruh variabel independen terhadap variabel dependen. Adapun rumus persamaan regresi Linier Berganda sebagai berikut:

$$
D P K=a+B_{1} P B_{t}+B_{2} \text { Kurst }+\Sigma_{t}
$$

Keterangan:

$$
\begin{array}{ll}
\text { DPK } & =\text { Variabel dependen (DPK Perbankan Syariah) } \\
a & =\text { Konstanta } \\
\text { PDB } & =\text { Variabel independen (PDB) } \\
\text { Kurs } & =\text { Variabel independen (KURS) } \\
\Sigma & =\text { Standard Error }
\end{array}
$$

\section{HASIL DAN PEMBAHASAN}

\section{Analisa hasil pengolahan dan pembahasan}

Berdasarkan data yang diperoleh kemudian diolah dengan menggunakan SPSS, maka didapatkan hasil sbb :

Analisa Asumsi Klasik

a. Uji Heterokedasitas adalah suatu keadaan dimana varian dari kesalahan pengganggu tidak konstan untuk semua nilai variabel bebas. 
b. Uji Autokorelasi merupakan korelasi antara anggota seri observasi yang disusun menurut urutan waktu (seperti data time series) atau menurut urutan tempat atau ruang (seperti data cross section), atau korelasi pada dirinya sendiri.

c. Uji Multikolinieritas merupakan keadaan dimana satu atau lebih variabel independen dinyatakan sebagai kondisi.

d. Uji Normalitas bertujuan untuk menguji apakah dalam model regresi variabel dependen, variabel independen atau keduanya mempunyai distribusi normal atau tidak, dan untuk mengetahui normal tidaknya data sample.

Analisis Regresi Berganda

Fungsi regresi

Fungsi regresi untuk PDB (produk Domestik Bruto) dan kurs rupiah terhadap dollar AS dengan DPK (Dana Pihak Ketiga) perbankan syariah di Indonesia yaitu :

DPK $=-1,2417+0,011$ PDB $-309,469$ Nilai Tukar.

Dari fungsi regresi data awal diatas, dapat diinterpretasikan bahwa :

Jika PDB (X1) dan kurs rupiah (X2) mendekati atau sama dengan 0, maka $Y=$ 1,2417. Dengan interpretasi bahwa jika PDB dan kurs rupiah rendah, maka rata-rata DPK tetap sebesar -1,2417. Artinya secara keseluruhan DPK perbankan syariah tetap, tidak terlalu baik.

Jika PDB (X1) naik satu satuan sedangkan kurs rupiah (X2) tetap, maka DPK (Y) akan naik sebesar 0,011 kali. Dengan interpretasi bahwa setiap peningkatan PDB sebesar 1 milyar rupiah, akan berdampak pada peningkatan DPK sebesar 0,011.

Jika kurs rupiah pada dollar AS (X2) naik 1 satuan sedangkan PDB (X1) tetap, maka Y akan turun sebesar 309,469 kali. Dengan interpretasi bahwa setiap peningkatan kurs rupiah akan berdampak penurunan DPK sebesar 309,469

Uji $F$ dilakukan untuk menguji apakah variabel bebas pengaruh terhadap variabel terikatnya secara stimultan. Diketahui bahwa nilai $F$ table $=3,47$ dan berdasarkan nilai $F$ hitung pada tabel ANOVA di atas adalah 283,714, ini menunjukan bahwa $F$ hitung > F tabel. Hasil ini juga didukung dengan nulai signifikan 0,000 lebih kecil dari nilai : 0,05. $\mathrm{Hal}$ ini berarti $\mathrm{H}_{0}$ ditolak dan $\mathrm{Ha}$ diterima atau secara statistik menyatakan bahwa variabel bebas berpengaruh terhadap variabel terikat. Dengan demikian dapat 
dinyatakan bahwa analisis yang didapatkan menunjang hipotesa yaitu PDB (Produk Domestik Bruto) dan kurs rupiah pada dollar AS memberikan pengaruh terhadap DPK perbankan syariah di Indonesia.

Uji t dilakukan untuk menguji apakah variabel bebas berpengaruh terhadap variabel terikatnya secara parsial. Diketahui bahwa nilai t table PDB $=2,0739$ dan berdasarkan nilai t hitung pada tabel diatas adalah 21,612, ini menunjukan bahwa t hitung $>$ tabel. Hasil ini juga didukung dengan nilai signifikan 0,000 lebih kecil dari nilai : 0,05. Hal ini berarti $\mathrm{HO}$ ditolak dan $\mathrm{Ha}$ diterima atau secara statistik menyatakan bahwa variabel bebas PDB berpengaruh terhadap variabel terikat DPK.

Uji Pearson Correlation (Koefisien korelasi)

Bertujuan untuk mengetahui korelasi antara PDB dan kurs rupiah pada dollar AS denga DPK perbankan syariah. Berdasarkan hasil empiris terlihat bahwa korelasi antara PDB dengan DPK adalah 0,982. Hal ini menunjukan adanya korelasi yang sangat kuat dan positif

Uji R Square (Koefisien determinant)

Berguna untuk mengukur seberapa besar kontribusi variabel bebas (X) terhadap variabel terikat $(Y)$ atau seberapa besar variabel $Y$ dijelaskan oleh variabel $(X)$

Berdasarkan hasil empiris nilai $R$ Square adalah 0,964. Hal ini menunjukan bahwa variabel PDB dan kurs rupiah pada dollar AS $(X)$ mempunyai pengaruh terhadap DPK perbankan syariah sebesar $96,4 \%$, sementara sisanya sebesar $3,6 \%$ dipengaruhi oleh faktor lain.

Variabel yang paling dominan berpengaruh terhadap DPK perbankan syariah di Indonesia. Variabel yang paling dominan mempengaruhi DPK perbankan syariah di Indonesia adalah PDB sebesar 0,982

\section{SIMPULAN}

Penelitian ini bersifat informatif belum begitu mendalam, sehingga dari penelitian ini masih bisa dilakukan penelitian lanjutan, dari variabel PDB masih bisa diurai lagi, komponen mana dari PDB yang lebih memiliki pengaruh terhadap peningkatan DPK perbankan syariah di Indonesia. 
Perbankan syariah sebaiknya lebih meningkatkan kualitas, seperti peningkatan pelayanan yang maksimum, sarana dan prasarana yang lebih lengkap, manajemen yang lebih mantap sehingga bersaing dengan bank konvensional sehingga banyak masyarakat yang tertarik untuk memindahkan dananya pada perbankan syariah.

\section{PUSTAKA ACUAN}

Agung, Bhuono. 2005. Strategi Jitu memilih Metode Statistik Penelitian dengan Menggunakan SPSS. Yogyakarta: CV. Andi Offset.

Amin, A. Riawan. 2009. Perbankan Syariah Sebagai Solusi Perekonomian Nasional. Jakarta : UIN Press.

Arifin, Zainul. 2006. Dasar-dasar Manajemen Bank Syariah. Jakarta: Pustaka Alvabet.

Ascarya. 2007. Akad \& Produk Bank Syariah. Jakarta : PT. Rajagrafindo Persada.

Chapra, M. Umer. 2000. Sistem Moneter Islam. Jakarta : Gema Insani Press.

Daniel, Moehar. 2003. Metode Penelitian Sosial Ekonomi. Jakarta : PT. Bumi Aksara.

Ghazali, Imam. 2006. Aplikasi Analisis Multivariatr dengan Program SPSS. Semarang, Badan Penerbit Undio.

Karim, Adiwarman A. 2007. Ekonomi Makro Islam. Jakarta : PT.Rajagrafindo Persada.

Kasmir. 2007. Manajemen Perbankan. Jakarta : PT. Rajagrafindo Persada.

Santoso, Singgih. 2000. Latihan SPSS Statistik Parametrik. Jakarta : PT.Elek Media Komputindo.

Sinungan, Muchdarsyah. 1993. Manajemen Dana Bank. Jakarta : PT. Bumi aksara.

Sukirno, Sadono. 2004. Makroekonomi Teori Pengantar. Jakarta : PT. Rajagrafindo Persada. 